\title{
THE NEEDS OF THE MANY AND THE NEEDS OF THE FEW: A NEW SYSTEM OF PUBLIC INTEREST INTERVENTION FOR NEW ZEALAND
}

\author{
Edward Clark*
}

\begin{abstract}
The traditional adversarial system sees the courts as simply a means of resolving disputes between private parties. The dispute is thus no one else's concern but the parties'. This view of the courts' role, however, fails to take into account judicial law-making. If a person is affected by an act of law-making, it is only just that they should have a chance to be heard. Further, before they make a decision the courts should understand the perspectives of those who will be affected by the rule laid down.

This article argues that allowing affected non-parties to make submissions as public interest intervenors will assist both the affected persons and the courts. In order to balance the interests of the parties, the intervenors, and the public at large effectively, a comprehensive system of rules that both welcome and regulate public interest intervention is needed. This article recommends the adoption of such a system of rules, substantially based on the effective and well-established rules on intervention contained in the Rules of the Supreme Court of Canada.
\end{abstract}

\section{INTRODUCTION}

The adversarial system is deeply rooted within the common law tradition. In a strict adversarial system, the litigation process is seen simply as a way to resolve disputes between the parties who enter into it. The courts play the role of neutral adjudicators who apply the law made by Parliament and declare the pre-existing common law. If this is the courts' sole function, then it can properly be said that the decision in a particular case is nobody's business but the parties.

It is not really tenable to say that the courts merely declare the law, however. Writing extrajudicially, Lord Reid has stated: ${ }^{1}$

* Submitted as part of the LLB(Hons) programme at Victoria University of Wellington.

1 Lord Reid "The Judge as Law Maker" (1972) 12 JSPTL 22, 22. 
There was a time when it was thought almost indecent to suggest that judges make law - they only declare it. Those with a taste for fairy tales seem to have thought that in some Aladdin's cave there is hidden the Common Law in all its splendour and that on a judge's appointment there descends on him knowledge of the magic words Open Sesame. ... But we do not believe in fairy tales any more.

Once it is accepted that the courts make law, it must also be accepted that in some cases the courts will lay down principles that affect people other than the parties to the litigation. ${ }^{2}$ This being the case, it is surely just that those who may be affected by a particular act of law-making have an opportunity to be heard in the decision-making process. Further, it is desirable that the court fully appreciates the points of view of those who will be affected by its decision.

The form of non-party intervention known variously as "public interest intervention", 3 "perspective intervention", ${ }_{4}$ and "interest group intervention" 5 is a way to achieve input from affected non-parties. This article will use the term "public interest intervention" to describe such intervention. This type of intervention allows a non-party to participate in litigation in order to "influence the judicial law-making process in a way the intervenor considers to be in the public interest." 6 By making submissions as to where the public interest in the case lies, the intervenor can both participate in the decision-making process and help the court understand the point of view of the affected group.

The relatively recent development of public interest intervention has followed the increasing acceptance of the law-making role of the courts that has developed internationally in the last few decades. However, the acceptance of public interest intervention has not occurred as universally as the acceptance of the law-making role. Judges seem to have accepted in the abstract that they make law affecting non-parties, but they have "tended to be reluctant to expand the opportunity to participate in the litigation to everyone so affected." 7 With a few exceptions, notably Canada, this reluctance is reflected by a relatively undeveloped system of public interest intervention in most Commonwealth jurisdictions. This reluctance to develop public interest intervention reflects the

2 Lord Reid's comment was about the common law, but I would suggest that the interpretation of statutes could in some circumstances constitute law-making as well, albeit within tighter constraints than developing the common law. See also Philip L Bryden "Public Interest Intervention in the Courts" (1987) Can Bar Rev 490,505 .

3 See Bryden, above n 2, 490.

4 See Andrea Loux "Hearing a 'Different Voice': Third Party Intervention in Criminal Appeals" (2000) 53 CLP 449, 460.

5 See Andrew Beck Principles of Civil Procedure (2 ed, Brookers, Wellington, 2001) 81.

6 Bryden, above n 2, 490 .

7 Bryden, above n 2, 507. 
general fear that public interest intervention will allow "...[the] mere busybody who is interfering in things which do not concern him" to unduly burden litigation. ${ }^{8}$

This article argues that the advantages of public interest intervention outweigh any disadvantages. Overseas experience has shown that a well-regulated system of public interest intervention can both assist the courts and increase public confidence in the judiciary. ${ }^{9}$ This article will argue that New Zealand should adopt a comprehensive system of rules "that both welcome and regulate" ${ }^{10}$ public interest intervention.

Part II briefly outlines what is meant by public interest intervention. Part III examines the routes by which non-parties can currently be heard in New Zealand and to what extent they allow participation by public interest intervenors. Part IV examines the most viable routes for public interest intervention in Canada, the United Kingdom, and Australia. It will also look at the various academic comments and criticisms that have been made about these systems, and assess their relevance to New Zealand. Part V outlines the advantages and disadvantages of public interest intervention, and the ways in which disadvantages can be curbed by regulation of the form, scope, and content of the intervention. Finally, drawing on New Zealand law and overseas experience, Part VI proposes a system of rules for the regulation of public interest intervention that would effectively balance the interests of the courts, the parties, and affected non-parties.

\section{WHAT IS PUBLIC INTEREST INTERVENTION?}

"Fundamental to the belief that public interest intervention is justified is the proposition that judges make law."11 The idea that judges make law has been accepted by such eminent jurists as Lord Reid, ${ }^{12}$ and Sir Anthony Mason, ${ }^{13}$ and I would suggest that this proposition can be accepted without too much trouble. Once this is accepted, it must also be recognised that members of the public who are affected by the principles laid down by a particular case, but are not parties to it, "have a legitimate interest in influencing the way in which this law-making power is exercised."14

$8 \quad$ Attorney-General of the Gambia v N'jie [1961] 2 All ER 504, 511 (PC) Lord Denning.

9 George Williams "The Amici Curiae and Intervener in the High Court of Australia: a Comparative Analysis" (2000) 28 FLR 365, 372-373.

10 Loux, above n 4, 470

11 Bryden, above n 2, 505. See also Sarah Hannett "Third Party Intervention: In the Public Interest" [2003] PL $128,128$.

12 Lord Reid, above n 1, 22.

13 Sir Anthony Mason "Interveners and Amici Curiae in the High Court: a Comment" (1998) 20 Adel LR 173, 173.

14 Bryden, above n 2, 505 
Public interest intervention is a way for people who are not concerned with the particular dispute between the parties, but are interested in the way a particular case will develop the law, to be heard.

More often than not, public interest intervention will be conducted by interest groups who represent such interested people. This intervention usually takes the form of the intervenor presenting submissions to the court to try to convince the court to develop the law in a particular manner. ${ }^{15}$ The public interest intervenor is not a full party to the proceeding, having fewer rights and liabilities than a party. Their intervention does not concern itself with the concrete facts of the dispute between the parties, just the legal issues that are of interest to them.

This sort of intervention can meaningfully be said to serve the public interest in two senses. ${ }^{16}$ First, the public interest intervenor will be seeking to convince the judge to give effect to the intervenor's conception of the public interest. This is a relatively narrow idea of public interest, and can often be seen to closely align with the private interests of the intervenor. ${ }^{17}$ Secondly, the interest of the public at large is served by the court having access to the expertise and fresh perspectives that the intervenor can bring to the matter. ${ }^{18}$

This is the type of intervention envisaged in this discussion of public interest intervention. The next Part will discuss the extent to which such intervention is allowed by the current law of New Zealand.

\section{CURRENT RULES ON INTERVENTION IN NEW ZEALAND}

Under the current law in New Zealand, there are several routes by which a person who is not an original party to a proceeding can seek to be heard. The first, and most common, is to seek leave to be joined as an additional defendant under Rule 97 of the High Court Rules (HCR). This is known as party intervention. There is also a developing form of intervention by which a non-party can seek to present submissions on the wider interests that may be affected by the decision in a particular case. Although this is technically a form of party intervention, it is treated somewhat differently and shares some aspects with the traditional role of the amici curiae. This type of intervention is the beginning of a New Zealand version of public interest intervention. A conceptually identical form of intervention is the long established ability of the Attorney-General to intervene to protect the

15 Bryden, above n 2, 490-491.

16 These two senses of the public interest will be discussed further in Part V A Advantages of Public Interest Intervention.

17 Bryden, above n 2, 491. Note, however, that distinctions between public and private interests are often very hard to draw.

18 See Mona Arshi and Colm O’Cinneide "Third Party Intervention: The Public Interest Reaffirmed" [2004] PL 69, 72. 
public interest. It is also possible for non-parties to be heard as amici curiae, either on application to the court or on the court's own motion.

This Part will outline the key elements of each of these forms of intervention. It will then evaluate the extent to which each form of intervention can accommodate a potential public interest intervenor.

\section{A Party Intervention}

Party intervention is governed by Rule 97 of the HCR, which relates to the striking out and addition of parties. Within the adversarial system parties are generally allowed to resolve their disputes without interference from outside interests. Extra parties will only be joined, therefore, when it is necessary to do so for the issue at hand to be fully resolved. Party intervenors can apply to be joined under Rule 97(1)(b) on the grounds that their "presence before the court may be necessary".

Rule 97(1)(b) gives relatively little assistance to the courts in performing this balancing act. ${ }^{19}$ To deal with this lack of guidance, a substantial body of case law has been developed on when the court has jurisdiction to join a non-party and, if there is jurisdiction, whether the Court should exercise its discretion to join them.

As formulated by McGechan on Procedure, the jurisdictional question to be asked is: ${ }^{20}$

Will the proposed defendant's rights against or liabilities to any party to the action in respect of the

subject-matter of the action be directly affected by any order which may be made in the action?

This test for jurisdiction is considerably more restrictive than the letter of Rule 97(1)(b).

This jurisdictional test seems to rule out the participation of a public interest intervenor looking to protect a wider interest. Unless the intervenor has a legal right or liability, they will not even get past this threshold. Even if the jurisdictional threshold is crossed, the test for the exercise of

19 Beck, above n 5, 66, sees the matter as one of balancing diverse interests:

On the one hand, there is a concern to ensure everyone interested in a particular matter is a party to the proceeding ... On the other hand, proceedings involving many parties are cumbersome and costly; it is also undesirable to impose litigation on an unwilling party who may be only marginally concerned with the matter.

20 Hon Justice R A McGechan McGechan on Procedure (Looseleaf, Brookers, Wellington, High Court Rules) para HR97.13 (last updated 19 December 2003). The leading cases on jurisdiction to join are Mainzeal Corp Ltd v Contractors Bonding Ltd (1989) 2 PRNZ 47 (HC) and Arklow Investments Ltd v Ngati Terangi Iwi Inc Soc (1 June 1994) CA42/94. 
discretion is even more restrictive. ${ }^{21}$ It is highly unlikely, then, that a public interest intervenor would ever successfully apply to be heard under Rule 97. Further, joinder as a party entails rights that are unnecessary for a public interest intervenor's purposes and liabilities that they would rather avoid. $^{22}$ Rule 97 is not a viable route for public interest intervention and remains a very narrow exception to a pure adversarial system.

\section{B Public Interest Intervention}

In recent years, a type of public interest intervention distinct from party intervention under Rule 97 has become more common. The jurisdiction for such intervention is found in different places for the High Court and the Court of Appeal. ${ }^{23}$

In the Court of Appeal, jurisdiction is found in Rule 19 of the Court of Appeal (Civil) Rules 1997. Rule 19(2) specifically allows the Court of Appeal to direct that notice of appeal be served on a non-party. ${ }^{24}$

The jurisdictional basis for such intervention in the High Court is nowhere explicitly stated. In Hosking $v$ Runting (Hosking), ${ }^{25}$ Randerson J suggested that it can be found in Rules 9 and 438(3) of the High Court Rules. ${ }^{26}$ Further, it is possible that such intervention can be founded in the inherent

21 The appropriate occasions for the court to exercise its discretion to join an additional party (where jurisdiction has been found to exist) are laid down by Henry J in Hallam v Ryan (1989) 3 PRNZ 132, 133 and $135(\mathrm{HC})$.

22 The difference in the rights and liabilities between party intervention and the developing area of public interest intervention will be discussed below in Part III B 1 How does this differ from party intervention?

23 There are no express provisions in the Supreme Court Rules 2004 that allow non-parties to be heard, but Rule 6(1) allows the Court to "give any directions that seem necessary for the just and expeditious resolution of the matter". This is similar to the wording of Rule 438(3) of the High Court Rules, which is part of the jurisdictional foundation of public interest intervention in the High Court. Though there has not been any case law on intervention in the Supreme Court, one would assume that the same principles as have been applied in the High Court and Court of Appeal would apply to the Supreme Court.

24 Rule 19(2) also provides jurisdiction to allow party intervention. This does not happen often, though, as most non-parties who have an interest that is best represented by appearance as a party have already been joined at the High Court stage.

25 Hosking v Runting (11 February 2003) HC AK CP527/02, Randerson J [Hosking].

26 Hosking, above n 25, para 7 Randerson J. Rule 9 deals with cases not provided for, while Rule 438(3) enables the Court to make such orders and to give such directions as appear best adapted to securing the just, expeditious and economic disposal of the proceeding. 
jurisdiction of the Court. ${ }^{27}$ Such inherent jurisdiction has been used in the analogous situation of allowing the Attorney-General to intervene as guardian of the public interest. ${ }^{28}$

The jurisprudence on these three sources of jurisdiction (Court of Appeal (Civil) Rules, High Court Rules, and the inherent jurisdiction) is guided by the same principles, and forms a coherent though sparse body of principle on the issue.

1 How does this differ from party intervention?

Technically, intervenors added to a proceeding using this route are parties as much as those added under Rule 97. They are, however, treated somewhat differently. It is likely that a public interest intervenor will be required to meet the additional costs to other parties occasioned by their intervention. ${ }^{29}$ It is uncertain whether a public interest intervenor will be liable for any costs beyond the costs occasioned by their intervention. New Zealand Fire Service Commission v Ivamy (Ivamy) seems to indicate not, ${ }^{30}$ but in Hosking, Randerson J states "that the Court has jurisdiction, if necessary, to make an order for costs in favour of any party to the proceeding against the interveners should the Court exercise its discretion to do so." ${ }^{31}$ They may also be unable to claim costs against the other parties. ${ }^{32}$ Further, the court can allow the intervenor to present written submissions but reserve the question of whether to hear counsel orally, calling on them only if the court sees fit. ${ }^{33}$

It is because of these differences in jurisdictional foundations, rights conferred and liabilities imposed that this form of intervention is to be distinguished from party intervention governed by Rule 97. This developing jurisdiction is certainly a form of public interest intervention.

\section{Principles governing public interest intervention}

The principles governing the court's discretion to grant public interest intervenor status have only recently been set down. In Zaoui v Attorney-General, ${ }^{34}$ the most recent application for interest

27 Hosking, above n 25, para 7 Randerson J.

28 Beck suggests public interest intervention is virtually identical to such intervention by the Attorney-General, apart from the breadth of the interest being advocated: that of a particular group as opposed to the public as a whole as represented by the Attorney-General. Beck, above n 5, 79 .

29 New Zealand Fire Service Commission v Ivamy (1995) 8 PRNZ 632, 634 (CA) Cooke P for the Court [Ivamy].

30 Ivamy, above n 29, 634 Cooke P for the Court.

31 Hosking, above n 25, para 16 Randerson J.

32 Hosking, above n 25, para 16 Randerson J; Zaoui v Attorney-General (No 1) (28 November 2003) HC AK CIV 2003-404-5872, 8 Williams J [Zaoui].

33 Drew v Attorney-General [2001] 2 NZLR 428, 432 (CA) McGrath J for the Court [Drew].

34 Zaoui, above n 32. 
group intervention, all the judgments cited by Williams $\mathrm{J}$ were delivered in the last 10 years. It should be noted, therefore, that this is a relatively new area of law that is still developing.

The leading cases regarding Rule 19(2) in the Court of Appeal are Wellington City Council v Woolworths NZ Ltd (Woolworths) ${ }^{35}$ and Ivamy. ${ }^{36}$ The relevant principles to come out of these cases, as distilled by McGechan on Procedure, are: ${ }^{37}$

(a) Although the $\mathrm{r}$ 19(2) power is wide, it should not be exercised as a matter of course or lightly: Ivamy (above, at p 633).

(c) The fact that a case raises issues of principle transcending the particular facts is not in itself sufficient to extend rights of hearing beyond the parties: Ivamy (above, at $\mathrm{p} 633$ ).

(d) However, where the case raises issues of general principle and wide importance, the Court can appropriately ask itself whether it would be assisted by submissions from the party or person sought to be joined: WCC $v$ Woolworths (above, at p 436).

Since Ivamy and Woolworths, the Court of Appeal in Drew v Attorney-General (Drew) has also laid down some additional principles which must be considered. Expanding on principle (d) above, the Court should allow intervention "[w]here the assistance likely to be offered outweighs any potential detriments to the various interests... ${ }^{138}$ Also, where the original parties have made it plain that they will provide full submissions, "the Court would expect an applicant for intervention to submit an affidavit outlining the general experience and expertise which it believes can assist the Court." 39

The overriding test, then, is whether the court can gain assistance from the intervenor's submissions that will go beyond the assistance that counsel from the parties can provide. Further, the assistance derived must outweigh any prejudice to the other parties. The onus is on the intervenor to prove both.

35 Wellington City Council v Woolworths New Zealand Ltd [1996] 2 NZLR 436 [Woolworths].

36 As stated above, the jurisdiction founding interest group intervention in the High Court is different from that in the Court of Appeal, but the High Court has accepted that the principles developed under Rule 19(2) are also relevant to the exercise of its discretion. See Hosking, above n 25, 4 Randerson J.

McGechan on Procedure, above n 20, para CA 19.02 (last updated 19 December 2003).

38 Drew, above n 33, 432 McGrath J for the Court.

39 Drew, above n 33, 432 McGrath J for the Court 


\section{When will public interest intervention be allowed?}

A variety of interest groups have been allowed to intervene to offer submissions on a range of factual and legal issues. The nature of the legal issues at stake and the identity of the intervenors in cases where public interest intervention has been allowed show a link between perceived expertise in the subject area and leave to intervene being granted. ${ }^{40}$ The intervention must be beneficial to the court as well as to the intervenor. ${ }^{41}$ As noted above, ${ }^{42}$ the fact that the case raises wider issues of principle transcending the particular facts and that a potential intervenor may have a legitimate interest in the development of such principles is not by itself a reason to allow intervention. These criteria are much easier for interested third parties to meet than those for party intervention under Rule 97.

\section{Intervention by the Attorney-General as Guardian of the Public Interest}

As mentioned above, intervention by the Attorney-General as guardian of the public interest is a form of public interest intervention. It has long been part of a Commonwealth Attorney-General's public interest function to appear in cases involving third parties. ${ }^{43}$

The current rule for public interest intervention by the Attorney-General was expounded in Auckland Area Health Board v Attorney-General, ${ }^{44}$ where Thomas J adopted the test used in the English case of Adams $v$ Adams ${ }^{45}$

40 Ivamy concerned rights to representation in contract negotiations under the Employment Contracts Act 1991 (Ivamy, above $\mathrm{n}$ 29). Both the Council of Trade Unions and the New Zealand Employers' Federation were granted leave to intervene. Woolworths was a rating appeal, that "raise[d] matters of general principle and public policy of fundamental importance to local authorities", in which Local Government New Zealand was granted leave to intervene (Woolworths, above n 35, 436 Richardson P for the Court). The New Zealand Council of Civil Liberties was granted leave to intervene in Drew, which centred on the rights of prisoners to be represented in disciplinary hearings (Drew, above n 33). Attorney-General v Daniels (2002) 16 PRNZ 771 (CA) concerned the mainstreaming of school children with disabilities, and the Human Rights Commission successfully applied to intervene. The Human Rights Commission also successfully applied to intervene in Zaoui, which concerned the continued detention of an asylum seeker on national security grounds (Zaoui, above n 32, 8 Williams J). In Hosking, which ultimately saw the development of a limited tort of privacy, both ACP Media Ltd (the largest magazine publisher in New Zealand) and the Commonwealth Press Union were allowed to intervene (Hosking, above n 25, para 16 Randerson J).

41 See comments to this effect in Hosking, above n 25, para 15 Randerson J.

42 See above $\mathrm{n} 37$ and accompanying text.

43 The public interest role of the Attorney-General is a vast topic, and full coverage is outside the scope of this paper. For a more extensive discussion of the history, principles, and practicalities surrounding this public interest role, see J L1 J Edwards The Law Officers of the Crown (Sweet \& Maxwell, London, 1964) and J L1 J Edwards The Attorney General: Politics and the Public Interest (Sweet \& Maxwell, London, 1984).

44 Auckland Area Health Board v Attorney-General [1993] 1 NZLR 235, 240-241 (HC) Thomas J [Auckland Area Health Board]. 
In my view the Attorney-General has a right of intervention in a private suit whenever it may affect the prerogatives of the Crown, including its relations with foreign States ... and he certainly has in such circumstances a locus standi at the invitation of the court ... or with the leave of the court... .

I think that the Attorney-General also has the right of intervention at the invitation or with the permission of the court where the suit raises any question of public policy on which the executive may have a view which it may desire to bring to the notice of the court.

This standard for intervention would seem to encompass both intervention by the AttorneyGeneral on behalf of the Crown itself and public interest intervention. ${ }^{46}$

As noted above, ${ }^{47}$ a general jurisdiction allowing public interest intervention from concerned non-parties is a very recent development. Public interest intervention by the New Zealand AttorneyGeneral, on the other hand, can be traced at least as far back as Re Rhodes in 1933. ${ }^{48}$ The increasing amount of public interest intervention by parties other than the Attorney-General can be explained by reference to the value modern New Zealand society places on diversity and multiculturalism. The concept of the public interest is very difficult to define in such a society, with many different groups having many different ideas of what constitutes the public interest. There is no way that the Attorney-General can possibly present all these different concepts of the public interest to the court in any one case. ${ }^{49}$

By contrast, the public interest role of the Attorney-General was developed over a century ago with a monolithic, majoritarian concept of the public interest. ${ }^{50}$ The Attorney-General was seen as

45 Adams v Adams [1970] 3 All ER 572, 576-577 Sir Jocelyn Simon P (PDA).

46 Auckland Area Health Board raised issues touching on both areas. The case considered whether switching off the life support of an incapacitated patient would expose doctors to liability for culpable homicide. The Crown's prerogatives were affected, as the judgment could affect the Crown's prosecutorial discretion. The case also involved matters of general public importance with which the Attorney-General believed he could usefully assist the Court. Thomas J granted leave for the Attorney-General to intervene on both grounds (Auckland Area Health Board, above n 44, 240 Thomas J).

47 See Part III B 2 Principles governing public interest intervention.

48 Re Rhodes [1933] NZLR 1348. In this case the Attorney-General (represented by the Solicitor-General) intervened to argue that the full bench of the Court of Appeal could not overrule the decision of a single bench of itself. A matter like this, involving the jurisdiction of the courts, was seen as relating to the public interest.

49 According to Kent Roach, "Attorneys-General will have a difficult job in pursuing the public interest in a world in which the very notion of a single public interest, let alone of a spokesperson for that interest, is so hotly contested", Kent Roach "The Attorney-General and the Charter Revisited" (2000) 50 UTLJ 1, 26.

50 Attorney-General v Garner is cited as an authoritative statement of what constitutes the public interest by the authors of McGechan on Procedure, above n 20, para HR 97.14(7) (last updated 19 December 2003). In this 1907 case, Channell J stated "... the rights ... which the Attorney-General intervenes in order to protect 
representative of the interest of the whole of society, not the divergent views of the social groups within such a society. This concept of the public interest is no longer appropriate in today's society. While the governmental view of the public interest is certainly one valid formulation of the public interest, today's reality is one of disagreement as to the nature of the public interest. ${ }^{51}$ The recent development of public interest intervention by private parties allows these divergent concepts of the public interest to be heard.

\section{Appearance as Amici Curiae}

The amici curiae is literally the "friend of the court". The role has expanded and changed somewhat in some jurisdictions (most notably the United States), to include a person who makes partisan submissions, but traditionally "the amici is a person, or bystander, who intervenes in proceedings to put submissions to a court not as a party, but in order to assist the court on a point of fact or law." 52 This can take the form of drawing the court's attention to some point of law or fact which has been overlooked, without partisan argument, or presenting opposing arguments when one side is unrepresented. ${ }^{53}$ This section examines how the amici curiae is used today, and whether the traditional role is still a distinct form of non-party appearance or if it has been irretrievably bound up with the new public interest intervention jurisdiction.

This traditional amici curiae role is a creature of common law. No provision exists for amici curiae in either legislation or the HCR. It arises out of "... the inherent jurisdiction of a court to request assistance in its deliberations from members of the legal profession." 54

The problem with the role of amici curiae today is that, as far as offering submissions on overlooked issues is concerned, the distinction between intervenors and amici curiae has been substantially blurred. An example is Newspaper Publishers Association of New Zealand Inc $v$ Family Court (NPANZ). ${ }^{55}$ The Attorney-General appeared in this case as intervenor. This

must be the rights of the community in general, and not rights of a limited portion of His Majesty's subjects ...", Attorney-General v Garner [1907] 2 KB 481, 487 (KB) Channell J (emphasis added).

51 For a discussion on the lack of consensus as to what constitutes the public interest, see Ian Scott "Law, Policy, and the Role of the Attorney-General: Constancy and Change in the 80s" (1989) 39 UTLJ 109, 109110 .

52 Williams, above n 9, 366.

53 McGechan on Procedure, above n 20, para J99A.02 (last updated 19 December 2003).

54 Williams, above n 9, 366-367 (footnote omitted).

55 Newspaper Publishers Association of New Zealand Inc v Family Court (NPANZ) [1999] NZFLR 397 (HC) [NPANZ]. In this case, the Newspaper Publishers Association challenged the granting of a suppression order by the Family Court in relation to the Liam Williams Holloway saga, when the parents of a young boy with cancer refused to let him be given conventional cancer treatment. Instead, they went into hiding and, in an attempt to find them, the Family Court released details of the case to the media. When it became clear that this strategy was not working, the Family Court issued the suppression order in dispute in NPANZ. 
intervention, according to the Court, gave them "the considerable benefit of the submissions from Ms France, being submissions advanced from a neutral standpoint." 56 This description of the Attorney-General's intervention exactly matches the traditional role of the amici curiae. The fact that such submissions were given on an intervenor basis indicates the lack of a clear distinction between appearance as amici curiae and appearance as intervenor.

This conceptual confusion can be seen when one compares the intervention in NPANZ with the appearance of non-parties in $Z v Z$ (No 2). ${ }^{57}$ In $Z v Z$ (No 2), a husband was disputing an award of his future earnings to his wife as part of the division of property on the break up of their marriage.

On the future earnings issue, a variety of interest groups, as well as the Solicitor-General, appeared as amici curiae. The Solicitor-General appeared at the Court's request, to "assist the Court on a range of public interest questions involved." ${ }^{18}$ No such public interest tag was attached to the other intervenors, who appeared by leave. Given that the interest groups included such ideologically opposed interests as the Auckland Women Lawyers' Association and Fathers' Rights and Equality Exchange, it is unlikely that submissions from these groups maintained the neutrality traditionally attached to submissions by amici curiae.

The comparison between these two cases shows that the courts do not see any practical difference between public interest intervention and appearance as an amici curiae. Neither form of non-party appearance is seen as more neutral or more partisan than the other. Traditionally, only submissions such as those presented by the Attorney-General and Solicitor-General respectively in $N P A N Z$ and $Z \vee Z$ (No 2) would be appropriate for someone appearing as an amici curiae. Given that the Attorney-General in NPANZ was granted status as intervenor rather than as amici, even though the submissions made seemed to fit perfectly within the amici framework, it seems that the institution of amici curiae has progressively been losing its meaning as a form of intervention independent of public interest intervention. ${ }^{59}$

\section{E Conclusion on the Current Rules on Intervention}

Of the routes that currently allow non-parties to appear, public interest intervention clearly offers the best chance for the public interest intervenor to be heard. The requirements of party intervention are too strict to allow intervention in the public interest, and the traditional amici curiae role is completely indistinct.

\footnotetext{
6 NPANZ, above n 55, 399 Pankhurst and Chisholm JJ.

$57 \quad Z v Z$ (No 2) [1997] 2 NZLR 258 (CA).

$58 \quad Z v Z$ (No 2), above n 57, 373 Judgment of the Court.
}

59 In Part VI B One Category of Public Interest Intervenor, I suggest that the institution of amici curiae should not remain an independent form of intervention in New Zealand. 
Public interest intervention is a developing area of law. Its jurisdictional foundations are hazy and indistinct, particularly in the High Court. This type of intervention has gone some way to regulating the hearing of wider interests, but does not provide enough certainty as to which applications for intervention will be accepted and which will be rejected. Neither is it certain what conditions will be attached to each application for public interest intervenor status if it is granted. The current system is in its infancy, and more development is needed. Part VI, will outline a suggested set of rules for a viable system of public interest intervention in New Zealand.

\section{PUBLIC INTEREST INTERVENTION IN OTHER COMMONWEALTH JURISDICTIONS}

A number of Commonwealth jurisdictions have, over the last two decades, increasingly developed distinct forms of non-party intervention. Following the passing of its Charter of Rights and Freedoms in 1982, ${ }^{60}$ Canada has led the development of this type of intervention, and other Commonwealth jurisdictions look to the Canadian system for guidance in developing their own rules on public interest intervention. ${ }^{61}$ The United Kingdom is at a similar stage to New Zealand, while Australia takes a somewhat more restrictive approach.

This Part will examine the most promising routes for public interest intervention in all three jurisdictions. It will focus on public interest intervention in the highest court of each jurisdiction. A closer examination of the strengths and deficiencies of the systems of intervention in these other jurisdictions will assist in the development of a more comprehensive and clear system for the regulation of public interest intervention in New Zealand.

\section{A Public Interest Intervention in the Supreme Court of Canada}

\section{Rules from 1987-2002}

The Rules of the Supreme Court of Canada have allowed significant participation by public interest groups since 1987. ${ }^{62}$ These 1987 Rules stayed in force until mid-2002, when the Supreme Court Rules were completely rewritten. The jurisprudence developed under the old rules is still worth studying, as the system worked extremely well for a number of years. Further, the new rules have changed very little, and the old rules have been influential in the development of intervention

60 Canadian Charter of Rights and Freedoms, Part I of the Constitution Act 1982 (Canada Act 1982 (UK), sch B).

61 See for example, extensive references made to the Canadian experience in a British context in Hannett, above n 11, and Loux, above n 4. In an Australian context, see Williams, above n 9.

62 Rules of the Supreme Court of Canada 1974, as amended by SOR/83-930, s 1 and SOR/87-292. 
laws in other Commonwealth countries. The effect of these old rules, as summarised by John Koch, was as follows: ${ }^{63}$

Rule 18(1) [allowing any party interested in an appeal to apply to intervene on any terms and conditions as a judge may determine] remained unchanged. Rule 18(2) outlined the procedures for filing an application. Rule 18(3) required that an applicant state not only its interest in the appeal, but also its grounds "for believing that the submissions will be useful to the Court and different from those of the parties." Rule 18(4) gives an intervenor the right to file a factum ... to twenty pages and precludes an intervenor from presenting oral arguments without a judicial order otherwise.

Although these rules appear restrictive, the Court's practice under them was to allow intervention fairly freely. The exact criteria to be used were left to the judges, and as such, an examination of the case law in the area is essential to understanding this area of Canadian law. ${ }^{64}$

The basic requirements for the exercise of discretion to allow intervention are that the applicant intervener proposes to offer submissions that are useful to the court and different from those of the parties, and that they have an interest in the matter. ${ }^{65}$ Any interest is potentially sufficient, ${ }^{66}$ and the "useful and different" criterion is "easily satisfied by an applicant who has ... expertise which can shed fresh light or provide new information on the matter." ${ }^{167}$

This threshold reveals the hybrid nature of public interest intervention in Canada. An interest in the litigation is necessary to allow intervention. This acknowledges the probability that the intervenor's submissions will be partisan. But such submissions must also be "useful and different". This requires that the intervention will be beneficial to the court. Thus, intervention must benefit both the intervenor and the court before it will be allowed. ${ }^{68}$

63 John Koch "Making Room: New Directions in Third Party Intervention" (1990) 48 U Toronto Faculty LR $151,162$.

64 The case law in this area is sparse, as written reasons by judges are unfortunately rare. A notable exception was Sopinka $\mathrm{J}$, and much can be gathered from examining his reasons for granting leave to intervene.

Reference re Workers' Compensation Act 1983 (Nfld) [1989] 2 SCR 335 [Workers' Compensation]

Workers' Compensation, above n 65, 339 Sopinka J, referring to Norcan Ltd v Lebrock [1969] SCR 665.

67 Workers' Compensation, above n 65, 340 Sopinka J. Sopinka J suggests that this expertise can be demonstrated by the applicant "showing a history of involvement in the issue".

68 Sharon Lavine catalogues some other considerations that are or have been used in deciding whether to gran leave to intervene, but these are not particularly relevant to this article. See further Sharon Lavine "Advocating Values: Public Interest Intervention in Charter Litigation" (1993) 2 NJCL 27, 48-53. 


\section{Rules from 2002}

The Rules of the Supreme Court of Canada were completely rewritten in 2002. The changes came into effect in June of that year. Among the changes was a revision of the old Rule 18 governing intervention. The provisions concerning intervention now make up Rules 55 to $59 .{ }^{69}$

The only substantive change in the effect of the rules is contained in Rule 59, which is simply a reflection of the previous de facto practice of determining leave to intervene and leave to present oral argument separately. It does not seem likely that the new Rules will have a significant effect on the jurisprudence developed under the old ones. It is too early to be certain, however. Rules 96 to 98 state that the new provisions only apply to appeals lodged after 28 June 2002 . There have been few judgments on appeals lodged after that date and, as of the time of writing, no written reasons given for leave to intervene.

Also of note is the fact that Rule 61 states the Attorneys-General have a right to intervene in constitutional questions. This rule requires anyone who intends to raise a constitutional question before the Supreme Court to notify both the federal and all of the provincial Attorneys-General. ${ }^{70}$ This would include all litigation touching on the interpretation of the Charter. The AttorneysGeneral then have a right to intervene without leave if they so wish. ${ }^{71}$ This rule reflects the fact that executive government will always have a proper interest in the interpretation and application of the Constitution under which they act.

\section{Criticisms of the system}

As discussed above, changes have recently been made to the Rules of the Supreme Court of Canada to address several perceived problems present in the old rules. This recent reform means that calls for change are limited.

What criticism there is essentially falls into one of two categories. The first is concerned with the amount of intervention that has become common. In an interview in March 2000, Justice Iacobucci of the Supreme Court expressed concern at the number of interveners at Supreme Court level, particularly in criminal appeals, with batteries of intervenors on each side upsetting the balance of the case. ${ }^{72}$

69 The Supreme Court of Canada has published what it believes the major effects of the Rule changes will be See Supreme Court of Canada "Major Changes to Rules of the Supreme Court of Canada" $<$ http://www.http://www.scc-csc.gc.ca/> (last accessed 6 May 2005).

70 Rules of the Supreme Court of Canada, r 61(3).

71 Rules of the Supreme Court of Canada, r 61(4).

72 K Mankin "Intervenors: how many are too many?" (10 March 2000) The Globe and Mail Toronto A2. 
The second argues against any public interest intervention. Proponents argue that public interest intervention allows political pressure groups without a popular mandate to try to change the law without going through the proper parliamentary procedures. That is, that such intervention is antidemocratic, and may also have the effect of politicising the judiciary. ${ }^{73}$ These arguments will be explored more fully below. ${ }^{74}$

\section{Relevance to New Zealand}

Canada has a far more developed system of public interest intervention than New Zealand does. The Rules of the Supreme Court of Canada are thus a useful source to examine when considering what sort of rules should be developed in New Zealand to regulate public interest intervention. While the principles outlined in New Zealand cases such as Ivamy, Woolworths, Drew and Hosking are broadly similar to those governing intervention in Canada, the New Zealand law is less specific and, importantly, has not been codified. The Canadian system provides more guidance to both parties and potential public interest intervenors as to when intervention will be granted and what conditions may be imposed.

\section{B Public Interest Intervention in the United Kingdom}

The categories of intervention in the United Kingdom are similar to those employed in New Zealand. Like New Zealand, the United Kingdom has a long history of both party intervention and, in particular, intervention by amici curiae. ${ }^{75}$ Also, like New Zealand, there is a developing jurisdiction for allowing public interest intervention. ${ }^{76}$ Hannett notes that applications to intervene on this basis, at least in the House of Lords, have risen considerably since the passing of the Human Rights Act 1998 (UK). ${ }^{77}$

\section{Principles of public interest intervention in the United Kingdom}

Like New Zealand, the United Kingdom has no unified jurisdictional foundation for public interest intervention. The source of jurisdiction varies between courts, as does the clarity of guidance. The House of Lords has the clearest procedural rules in this area, but these still provide little guidance. ${ }^{78}$ In the High Court, intervention is governed by various different parts of the Civil

\footnotetext{
For an outline of some of these reservations see Hannett, above n 11, 137-140.

4 See Part V B Disadvantages of Public Interest Intervention.

Hannett, above n 11, 129-131.

6 Hannett, above n 11, 131-134.

7 Hannett, above n 11, 132 .

78 See House of Lords Practice Directions and Standing Orders Applicable to Civil Appeals, Direction 36. An identical provision exists in the Practice Directions and Standing Orders Applicable to Criminal Appeals.
} 
Procedure Rules, with different rules governing intervention in judicial review proceedings,${ }^{79}$ and private law proceedings. ${ }^{80}$ The Court could also rely on its inherent jurisdiction. ${ }^{81}$ None of these sources of jurisdiction give any guidance as to how the discretion to hear non-party intervenors should be exercised.

Case law also offers only limited guidance. Third parties have been allowed to intervene because of their "knowledge ... concern and ... experience." 82 Intervention has also been allowed where the intervenor intends to raise issues of public interest that have not been addressed by the parties. ${ }^{83}$ The most authoritative judicial statement on the issue comes from Lord Woolf, who states that the determinative factor in deciding intervention applications is whether the intervention will serve the interests of justice and in particular assist the court. ${ }^{84}$ This potential assistance must be balanced against the "inconvenience, delay and expense" that such intervention will occasion. ${ }^{85}$ Such an approach is markedly similar to the Canadian threshold criteria. ${ }^{86}$

As in Canada, the Crown is given a privileged position in terms of intervention in some constitutional litigation. In the case of the United Kingdom, this takes the form of section 5 of the Human Rights Act 1998 (UK). This section gives the Crown a right to intervene in any litigation where there is the possibility of a declaration of incompatibility being made in accordance with section 4 of the Human Rights Act 1998 (UK). This right of intervention can be explained as recognition of the fact that the Crown ought to be given the opportunity to explain or defend the legislation that is under attack.

79 Civil Procedure Rules (UK), r 54.17.

80 Civil Procedure Rules (UK), r 19.2(2).

81 See Grobbelaar v News Group Newspapers Ltd [2002] 4 All ER 732, para 25 (HL) Lord Bingham citing I H Jacob "The Inherent Jurisdiction of the Court" (1970) 23 CLP 23, 51.

$82 R v$ Monopolies and Mergers Commission and Secretary of State for the Trade and Industry Ex Parte Milk Marque Ltd [2000] COD 329, 330 (QB) Moses J.

83 See for example $R v$ Department of Health Ex Parte Source Informatics [2000] COD 114 (QB).

84 Re Northern Ireland Human Rights Commission [2002] UKHL 25, para 34 (HL) Lord Woolf.

85 Re Northern Ireland Human Rights Commission, above n 84, para 34 Lord Woolf.

86 Lord Steyn has made the similarity between the English and Canadian systems even more apparent, stating in an interview that two critical criteria are "that the party seeking leave has some demonstrable interest in the case (which could be a wider public interest) and that the intervention would aid the court in its decision-making process." Hannett, above n 11, 143-144 citing an interview with Lord Steyn (24 June 2002). 


\section{Criticisms of the system}

The development of the public interest jurisdiction in the United Kingdom has attracted considerable comment. ${ }^{87}$ Some commentators have welcomed the growth in such intervention, while others have expressed considerable reservations. ${ }^{88}$ All these commentators, though, regardless of their opinion on the value of public interest intervention, have called for greater clarity from the judiciary as to when such interventions will be allowed.

As well as this lack of clear criteria for regulating public interest intervention, Hannett has complained of a lack of conceptual clarity between different types of intervention. The courts in the United Kingdom "have not expressly recognised a category of intervention in the public interest, and do not explicitly identify when interventions are heard in the public interest." 89 This has resulted, according to Hannett, in a "widespread conflation of the categories of intervention." 90

Hannett has outlined a number of other problems she sees with the development of public interest intervention in the United Kingdom. These are: a lack of democratic mandate backing public interest intervenors; ${ }^{91}$ the politicising effect public interest intervention has on the judiciary; ${ }^{92}$ and the impact of intervention on the parties. ${ }^{93}$ These broad criticisms will be discussed further below. ${ }^{94}$

\section{Relevance to New Zealand}

The public interest intervention jurisdiction in the United Kingdom is at a similar stage of development to that of New Zealand. The substantive law itself is quite similar and not particularly useful in providing inspiration for reform. The academic criticisms and suggestions for reform, however, are broadly applicable to New Zealand, and are of use in pinpointing the areas of New Zealand law that are in need of reform. The key point to take from the system of public interest intervention in the United Kingdom is that principles developed in case law are not sufficient to properly regulate intervention. Additions to the relevant rules of procedure are required. Commentators in the United Kingdom have also noticed a similar conflation of the traditional amici

87 See for example, Arshi and O'Cinneide, above n 18; Loux, above n 4; Sandra Fredman "Judging Democracy: The Role of the Judiciary Under the Human Rights Act 1998" (2000) 53 CLP 99.

See for example, Hannett, above n 11; Carol Harlow "Public Law and Popular Justice" (2002) 65 MLR 1, 7.

Hannett, above n 11, 133.

Hannett, above n 11, 133

Hannett, above n 11, 135-137.

Hannett, above n 11, 137-140.

Hannett, above n 11, 140-141.

See Part V B Disadvantages of Public Interest Intervention. 
curiae role with other forms of intervention, and the call for greater clarity here is also useful to consider.

\section{Public Interest Intervention in the High Court of Australia}

The public interest form of intervention is not as well developed in the High Court of Australia as it is in New Zealand. The jurisdiction is more restricted and the jurisprudence on the issue sparse. There is, however, more agitation for change in Australia than there has been in New Zealand. There has therefore been a considerable amount of writing urging reform in the area of intervention in recent years.

\section{Principles of public interest intervention in the High Court of Australia}

As with the other countries considered, the task of analysing the principles governing public interest intervention is made extremely difficult by the scarcity of detailed written reasons for granting or declining leave to intervene. In Australia, it is common for no reasons to be given, even when leave is refused. ${ }^{95}$

There is no specific authority allowing the High Court to hear amici curiae or intervenors. The jurisdiction to do so is seen as part of the inherent jurisdiction, ${ }^{96}$ or possibly as inferred from the Judiciary Act 1903 (Cth). ${ }^{97}$ According to Williams, "[w]hatever the source of jurisdiction, it is accepted that when, and by what means, submissions will be accepted from interveners are matters entirely within the discretion of the Court."198

Historically, this discretion has been exercised very sparingly, and only those who have had a particular legal right, power, or immunity that will be affected by the litigation have been allowed to appear. ${ }^{99}$ This restrictive approach, which would all but limit intervention to strict party intervention, remained the norm until the mid-1990s. ${ }^{100}$ Since then, while still remaining very restrictive, the High Court has widened the potential avenues for intervention slightly. ${ }^{101}$ Specifically, "where a substantial affection of a person's legal interests is demonstrable (as in the case of a party to pending litigation) or likely, a precondition for the grant of leave to intervene is

95 Williams, above n 9, 366-367

96 Williams, above n 9, 377 .

97 Williams, above n 9, 377.

98 Williams, above n 9, 377.

99 Australian Railways Union v Victorian Railways Commissioners (1930) 44 CLR 319, 331 (HCA) Dixon J.

100 For a survey of the development of intervention in the 1990s, see Hon Justice Susan Kenny "Interveners and Amici Curiae in the High Court" (1998) 20 Adel LR 159, 161-167.

101 See Lange v Australian Broadcasting Commission (1997) 189 CLR 520 (HCA) and Levy v Victoria (1997) 189 CLR 579 (HCA) [Levy]. 
satisfied."102 Even if this threshold test is fulfilled, the applicant intervenor's submissions must provide a perspective to the Court that has not been sufficiently covered by any of the existing parties. ${ }^{103}$ The scope for public interest intervention here is narrow.

Interestingly, decisions on amici curiae and intervenors are said to be made on a different, wider set of principles. ${ }^{104}$ This is puzzling when the distinction between the two in an Australian context seems unclear. Writing extra-judicially, Kenny $\mathrm{J}$ has suggested that "it is accepted that the amici may enter into partisan advocacy", ${ }^{105}$ a contention which Williams rejects. ${ }^{106}$ If Kenny J's statement is accepted, though, then the distinction between a public interest intervenor and an amici curiae becomes unclear, and it is questionable whether the traditional role of amici curiae can be meaningfully said to exist as an independent form of intervention.

The jurisdiction to allow public interest intervention, then, is very limited. The jurisdiction to hear from amici curiae is wider, but as there are no standards set down as to how this extremely wide discretion is to be exercised, it is very difficult to see the extent to which the role of amici curiae can be used to facilitate public interest intervention.

As in Canada and the United Kingdom, governmental interests are somewhat privileged in some areas of intervention. Federal and State Attorneys-General must be notified of any matter which gives rise to a constitutional issue, ${ }^{107}$ and have a right to intervene in any matter arising under the Constitution or concerning its interpretation. ${ }^{108}$ This right to intervene is simply recognition that the Crown is a proper party in any litigation involving the Constitution.

\section{Criticisms of the system}

As noted above, there have been widespread calls for reform of the law of public interest intervention in Australia. At the most basic level, the reluctance to allow public interest intervention is seen as inconsistent with the use of this form of intervention overseas, particularly in the United

102 Levy, above n 101, 602 Brennan CJ.

103 Levy, above n 101, 603 Brennan CJ.

104 Brennan CJ also suggested in Levy, above n 101, 604 that an amici curiae need not have any interest in the proceedings, and that the hearing of an amici was entirely a matter of discretion:

That discretion is exercised on a different basis from that which governs the allowance of intervention. The footing on which an amici curiae is heard is that that person is willing to offer the Court a submission on law or relevant fact which will assist the court in a way which the Court would not otherwise have been assisted.

105 Kenny, above n 100, 161 .

106 Williams, above n 9, 400.

107 Judiciary Act 1903 (Cth), s 78B.

108 Judiciary Act 1903 (Cth), s 78A(1). 
States and Canada. ${ }^{109}$ As in the United Kingdom, the lack of procedural rules regulating intervention has been the target of particular criticism by a variety of commentators. ${ }^{110}$ Indeed, the Australian Law Reform Commission has recommended that rules be introduced to regulate such intervention. ${ }^{111}$ It has also been suggested that "[t]he failure of the High Court to admit public interest interveners is inconsistent with its recognition of the role it plays in making law." ${ }^{112}$ That is, that the Court has retreated excessively into outmoded legalism. ${ }^{113}$

\section{Relevance to New Zealand}

As stated above, the Australian system of public interest intervention is less well developed than that of New Zealand. While it would appear that the amici curiae jurisdiction is being expanded to create a category of intervention similar to public interest intervention in New Zealand, there has been no clear explanation of what principles apply to intervention by amici curiae. If, as I contend, New Zealand needs a more comprehensive system of regulation for public interest intervention, then there is little that can be taken from the existing Australian law.

The underdeveloped nature of the Australian system of intervention, though, means that there has been a substantial amount of literature calling for reform and proposing substantive changes. As in the United Kingdom and New Zealand, a conflation between amici curiae and intervenor has been noted and criticised by some commentators. ${ }^{114}$ At a more general level, both Williams and Kenny $\mathrm{J}$ have proposed systems of rules to regulate public interest intervention. ${ }^{115}$ Several of their eminently sensible suggestions for reform will be drawn on in proposing a new system of rules for New Zealand.

\section{BALANCING INTERESTS: THE ADVANTAGES AND DISADVANTAGES OF PUBLIC INTEREST INTERVENTION}

There have been many arguments made both for and against public interest intervention. Given the fact that all of the four jurisdictions explored above allow some public interest intervention, the question of whether or not such intervention should be allowed is not a useful one to ask. It is universally seen of some value to have public interest intervention at least occasionally. A more

109 Williams, above n 9, 392.

110 See for example, Williams, above n 9, 389; Kenny, above n 100, 169; Mason, above n 13, 175.

111 Australian Law Reform Commission Beyond the Door-Keeper: Standing to Sue for Public Remedies (ALRC 78, Canberra, 1996) paras 6.31-6.32 [Beyond the Door-Keeper].

112 Williams, above n 9, 393; see also Mason, above n 13, 173.

113 Williams, above n 9, 393-394.

114 Williams, above n 9, 400.

115 Williams, above n 9, 399-402; Kenny, above n 98, 169-171. 
pertinent question is to what extent public interest intervention should be allowed. This Part will address the arguments both for and against public interest intervention, and attempt to address the arguments against it by suggesting various forms of restriction on both the scope and form of intervention.

\section{A Advantages of Public Interest Intervention}

As discussed in Part II, public interest intervention serves two different conceptions of the public interest. The narrower conception of the public interest, held by the group on behalf of whom intervention is occurring, is advanced by giving that group a chance to be heard in a decision which affects them. The wider idea of the general public interest is served by the courts being allowed access to the expertise offered by the public interest intervenor. ${ }^{116}$ This section will explore both of these advantages.

\section{Participation and legitimisation}

As outlined in Part II, some people who do not have legal rights at issue in a particular case can be substantially affected by its outcome. Public interest intervention offers these affected people the chance to participate in an important part of the law-making process. This argument is strengthened if the persons affected are part of a minority group, because such groups have limited power to affect the law by electoral means. The development of the common law is thus of particular interest to them.

Participation in the decision-making process enhances the legitimacy of decisions, even when the intervention does not appear to affect the final outcome. ${ }^{117}$ By allowing people to present their perspective in a decision which affects them, the government is showing that it respects their human dignity and self-respect. ${ }^{118}$ Loux makes the point that these legitimising functions cannot be performed by an amici curiae. ${ }^{119}$ An amici curiae is traditionally a neutral figure and, unlike a public interest intervenor, does not "come to the Court with an established point of view."120

116 Arshi and O’Cinneide, above n 18, 72-73

117 Bryden, above n 2, 509.

118 Bryden, above n 2, 509, expresses this point eloquently, stating:

Scholars often disagree about the extent to which "dignitary values" require us to afford people the opportunity to take part in the process of defining our legal rights and obligations, but I think few would deny that our respect for courts and other governmental institutions is enhanced by their willingness to have regard for these values.

119 Loux, above n 4, 462.

120 Loux, above n 4, 463. 
Submissions from a neutral party (such as an amici curiae) will not serve to legitimise the court decision in the eyes of the affected group. ${ }^{121}$

\section{Assisting the court}

The core argument in favour of public interest intervention is that it helps courts reach better decisions and, in acknowledging their law-making role, make better law. ${ }^{122}$ This assistance to the court takes two forms: public interest intervenors can provide both relevant expertise and relevant perspectives to a court. ${ }^{123}$

The groups that most often seek to appear as public interest intervenors usually have particular expertise on the areas of law with which they are concerned. ${ }^{124}$ As Loux puts it: ${ }^{125}$

The experience in Canada has been that specialised human rights, feminist, and other organizations have

at their fingertips a wealth of information that for reasons of time ... [or] resources ... are unavailable to

the average barrister or advocate.

Loux believes that courts in the United Kingdom (where she is writing) would benefit from the experience such groups can offer. ${ }^{126}$ Equally, I would suggest that New Zealand courts would benefit from expert input by interest groups. ${ }^{127}$

As well as having expertise on the particular legal issues, public interest intervenors can offer a fresh perspective on the facts surrounding the case and the potential impact of the decision. ${ }^{128}$ When a decision has a particular effect on a minority group, the majority of the judiciary have nothing more than a superficial understanding of that minority perspective. ${ }^{129}$ Unless the particular

121 By contrast if, for example, an anti-abortion group is granted leave to intervene in a case involving abortion, the anti-abortion interests will publicly be seen to have participated in the decision-making process.

122 Arshi and O'Cinneide, above n 18, 72.

123 Arshi and O'Cinneide, above n 18, 72 .

124 Arshi and O'Cinneide, above n 18, 72; Kenny, above n 100, 168.

125 Loux, above n 4, 459.

126 Loux, above n 4, 459.

127 Though Loux does not spell out who exactly "other organisations" might be, they would presumably include industry associations and unions such as the New Zealand Employers' Federation and the New Zealand Council of Trade Unions, both of whom intervened in Ivamy (above n 29, 634 Cooke P for the Court). Such groups will have as much expertise within their particular areas of concern as the interest groups mentioned by Loux do in theirs.

128 Bryden, above n 2, 507.

129 Loux, above n 4, 467. 
judge is a member of the affected minority, they are unlikely to accurately appreciate how the decision will affect that minority.

Without input from the affected minority, the court is likely to deal with the potential effect on the minority in one of three ways. First, the judge could simply not recognise the wider impact of the decision and fail to consider it at all. Secondly, they could recognise the interest, and attempt to ensure that all interests are treated formally the same by deciding the case on abstract, universally applicable principles. ${ }^{130}$ This is a more satisfactory way to come to the decision, but still fails to consider the special interest of the minority. ${ }^{131}$ Finally, they could consider the interest and make their decision based on popular stereotype. ${ }^{132}$ This is plainly unacceptable.

To illustrate the usefulness of "hearing a different voice", ${ }^{133}$ Loux uses the example of an obscenity trial concerning gay and lesbian art and erotica. ${ }^{134}$ In Little Sisters Book and Art Emporium v Minister of Justice, it was accepted by a Canadian court that: ${ }^{135}$

[S] exual text and imagery produced for homosexuals serves as an affirmation of their sexuality and as a socialising force; that it normalises sexual practices that the larger society has historically considered to be deviant ... Because sexual practices are so integral to homosexual culture, any law proscribing representations of sexual practices will necessarily affect homosexuals to a greater extent than it will other groups in society.

If a court does not have the advantage of hearing submissions from a homosexual perspective, they will most likely not appreciate the importance of erotica in the gay and lesbian community. ${ }^{136}$ Reaching a verdict solely on freedom of expression principles would mean that the judges failed to consider the very real additional effect such censorship would have on the gay and lesbian community. Hearing submissions from a public interest intervenor in cases such as this is a way of drawing all relevant perspectives to the court's attention and thus improving the quality of the decision.

130 Loux, above n 4, 467

131 Loux, above n 4, 467.

132 Loux, above n 4, 468.

133 Loux, above n 4, 465

134 Loux, above n 4, 465-468.

135 Little Sisters Book and Art Emporium v Minister of Justice (1996) 131 DLR (4 $\left.{ }^{\text {th }}\right)$ 486, 522 (BCSC) Smith J.

136 Loux, above n 4, 467. 


\section{B Disadvantages of Public Interest Intervention}

Criticisms of public interest intervention centre on the perceived negative effect it will have on both the parties and the courts. This section will outline these criticisms and suggest how the negative effects identified can be limited.

\section{Effect on the parties}

As discussed above, ${ }^{137}$ the usual position in the adversarial system is that only the necessary parties to a dispute are heard in court, and it is the parties who decide which issues will be argued. Plainly, allowing a third party intervenor to be heard compromises this strict inter partes approach. ${ }^{138}$ A public interest intervenor is an added participant to litigation who may raise arguments that neither party wished to air. It can therefore be argued that the practice of third party intervention is incompatible with the common law adversarial tradition and unjust to the parties, who may find their position undermined by the intervenor's submissions. ${ }^{139}$

As a point of principle, this argument is not strong. Under a strict adversarial approach, the judge should not consider any rules of law or facts not raised by the parties. Law clerks today frequently draw relevant facts and legal authorities to the attention of their judges, however, and it is difficult to say that this practice is contrary to principle or unjust to the parties. ${ }^{140}$ Indeed, most people would agree that the judicial system is better off when judges are allowed such assistance. ${ }^{141}$ When considered from this perspective, it is difficult to say that public interest intervention is incompatible with the basic principles of the adversarial system.

At a practical level, the arguments against public interest intervention are stronger. The addition of more participants to litigation will inevitably increase the time taken and the costs incurred. ${ }^{142}$ This increase in time and expense is particularly likely where the intervenor seeks to expand the range of issues in dispute. ${ }^{143}$ This compromises the right of the parties "to come to court to resolve disputes expeditiously and at a minimum cost."144

\footnotetext{
137 See Part III A Party Intervention.

138 Bryden, above n 2, 507.

139 Hannett, above n 11, 140-141; Kenny, above n 100, 167.

140 Arshi and O'Cinneide, above n 18, 74.

141 Bryden, above n 2, 508

142 Kenny, above n 100, 167; Hannett, above n 11, 140.

143 Kenny, above n 100, 167; Bryden, above n 2, 514.

144 Bryden, above n 2, 514
} 
These detrimental effects on the parties can be mitigated to a significant extent by proper regulation of intervention. Requiring the public interest intervenor to meet any additional costs occasioned by the intervention can relieve the costs burden. ${ }^{145}$ Orders to this effect were made in Ivamy. ${ }^{146}$ Giving the court a discretion to limit the scope of the intervention can prevent inappropriate expansion of the issues. ${ }^{147}$ Restricting oral argument and making written submissions the primary mode of public interest intervention can reduce the overall time and expense occasioned by public interest intervention. ${ }^{148}$ Further, public interest intervenors who, in the court's opinion, are seeking to make very similar points can be directed to combine their submissions. ${ }^{149}$

The effect of public interest intervention on the parties is considerable. However, if these forms of regulation are placed on public interest intervention, the benefits of public interest intervention can be enjoyed without unduly harming the interests of the parties.

\section{Effect on the courts}

There are several serious arguments that suggest that public interest intervention could have a detrimental impact on the court system. Inevitably, the appearance of a public interest intervenor will increase the court time taken up with a particular case. Those opposed to public interest intervention argue that such use of the court's time is a waste of scarce judicial resources. ${ }^{150} \mathrm{Such}$ allegations are, however, exaggerated.

The demands on the court's time can be limited in the same way as the expenses of the parties are mitigated: by restrictions on the scope and manner of intervention and by the consolidation of similar interventions. ${ }^{151}$ Interventions that will not be of use to the court can be filtered out at the stage of granting or denying leave to intervene. This means that unhelpful public interest intervenors will not be granted leave. ${ }^{152}$ The argument that public interest intervention inappropriately wastes court time is therefore not strong.

145 Williams, above n 9, 401; Kenny, above n 100, 170

146 Ivamy, above n 29, 634 Cooke P for the Court.

147 Bryden, above n 2, 526.

148 Bryden, above n 2, 519; Kenny, above n 100, 170.

149 Bryden, above n 2, 518-519; Williams, above n 9, 400-401.

150 Bryden, above n 2, 517.

151 See Part V B 1 Effect on the parties.

152 It should be noted that some form of requirement that a potential public interest intervenor must be able to provide useful information to the court that is different from the submissions of the parties is part of the leave requirements in all of the jurisdictions this article has explored. 
Another allegation is that public interest intervention will result in the politicisation of the judiciary. Hannett suggests that intervention is merely a courteous form of political lobbying, the aim being to convince the court it is out of step with public opinion. ${ }^{153}$ This, she argues, potentially exposes the court to political pressure from numerous interest groups. ${ }^{154}$ "The result is that judicial adjudication becomes more akin to the legislative process", with interventions attempting to take the place of public consultation and parliamentary debate. ${ }^{155}$

This argument severely overstates the effect that intervention will have on the judicial process. As discussed above, ${ }^{156}$ it is now widely accepted that judges make law. The existence of the common law is proof of this law-making function. The argument also fails to take into account the fact that in a Westminster-style democracy like New Zealand, Parliament ultimately has the final say. If Parliament does not like the direction in which the judiciary has taken the law, it can step in.

Further, whenever a statute gives a judge broad discretion, Parliament inevitably leaves the judge to make some inherently political decisions. When a judge is attempting to determine what constitutes the welfare of the child under section 23 of the Guardianship Act 1968, a host of political considerations can come into the balancing exercise. Is it better for the child to be with its wealthy mother and her lesbian partner or its single, low income father? Should the child go to a religious or a secular school? Making this type of political decision has always been part of the judicial role. ${ }^{157}$ Public interest intervention is unlikely to make the judiciary any more political than it already is but, as noted above, it will make it more likely that when they have to make a politically-charged decision, they will reach it fully informed. ${ }^{158}$

Finally, there is an argument that by selecting some intervenors and declining others, the principle of equality before the law will be undermined. Hannett suggests that the court does not have the ability to identify all the relevant conceptions of the public interest that may be at stake, and to summon all the expertise it needs to fully understand these perspectives. ${ }^{159}$ Either irrelevant perspectives will be admitted or relevant ones will be left out. More fundamentally, she argues that a single intervenor cannot represent a whole group, and there will always be those within a

153 Hannett, above n 11, 138.

154 Hannett, above n 11, 138.

155 Hannett, above n 11, 139.

156 See Part V A 1 Participation and legitimisation.

157 This political role was increased in New Zealand with the enactment of the New Zealand Bill of Rights Act 1990 (BORA). Section 5 requires a judge to determine whether any particular limitation of a fundamental right is a reasonable limitation that can be demonstrably justified in a free and democratic society. Such an assessment is intensely political, with or without intervenors.

158 See Part V A 2 Assisting the court; see also Arshi and O'Cinneide, above n 18, 73.

159 Hannett, above n 11, 135-136. 
particular group who disagree with the stand taken by the person who has purported to intervene on their behalf. 160 These arguments are strong, and significantly weaken the claim that intervention can serve as a form of democratic participation for traditionally marginalised groups. ${ }^{161}$ They do not, however, address the core claim that public interest intervention helps the courts reach better decisions. $^{162}$

\section{Striking the Balance}

Neither completely unrestricted public interest intervention nor a total ban on it are viable options. The former is too burdensome on both the parties and the courts, while the latter means that judges miss out on the important contribution that public interest intervenors can make. The most sensible option for New Zealand is a regulated system of public interest intervention. Part VI will detail a proposed system of rules for New Zealand.

\section{A NEW SYSTEM OF PUBLIC INTEREST INTERVENTION FOR NEW ZEALAND}

All of the overseas jurisdictions explored in this article recognise the importance of rules to regulate public interest intervention. Kenny $\mathrm{J}$ has recognised that, whatever the approach to intervention taken in a particular jurisdiction: ${ }^{163}$

... [It is] important that the position of public interest interveners be acknowledged expressly in appropriate Rules of Court and that the legal profession be made aware of the principles upon which decisions to grant or to deny intervener ... status are made, in order to enable counsel to advise and assist their clients.

New Zealand should take note of this and other sensible comments from overseas and develop new rules of procedure for the regulation of public interest intervention (the New Rules). These New Rules can to some extent be based on the current law of New Zealand and should also draw on the effective and well-established Rules of the Supreme Court of Canada. In some areas of law, the New Zealand position is substantially acceptable. In other areas it is plainly deficient, and comparative material must be drawn on. In both situations, clear, codified rules are required to bring clarity to a complicated area of law.

The remainder of this Part will outline the matters that should be included in the New Rules. These New Rules should be included in all relevant rules of procedure at all levels of the court

\footnotetext{
160 Hannett, above n 11, 136-137.

161 See Part V A 1 Participation and Legitimisation.

162 Arshi and O'Cinneide, above n 18, 72.

163 Kenny, above n 100, 170.
} 
system. Any contextual differences between public interest intervention in trial and appellate courts can be dealt with effectively by the discretion left to the judge.

\section{A The Role of the Attorney-General}

The criteria set out in Auckland Area Health Board should continue to be used. ${ }^{164}$ The New Rules should recognise the Attorney-General's right to intervene in cases which concern the Crown prerogative. Outside this area, the Attorney-General should be treated the same as any other public interest intervenor. This is largely a codification of the existing New Zealand law, and is also in line with the law of the other jurisdictions referred to.

\section{B One Category of Public Interest Intervenor}

Instead of using party intervention and attaching special conditions to facilitate public interest intervention, a new category of intervenor should be established, sharing some aspects of party intervention and some aspects of the traditional amici curiae role. The conceptual distinction between the amici curiae role and public interest intervention is no longer clear in New Zealand. A similar blurring of the boundaries between the amici curiae role and intervention has also occurred in Australia and the United Kingdom. A single form of public interest intervention would help resolve some of the conceptual confusion commentators such as Hannett have identified overseas.

As has been proposed by the Law Reform Commission in Australia, appearance as amicus curiae should be abolished as a form of intervention and a generic category of public interest intervenor should be created, encompassing both the current form of public interest intervention and the role of amici curiae. ${ }^{165}$ The amici curiae should be reserved for cases in which the Court wishes to appoint counsel to represent an absent party or contradict an unopposed argument. ${ }^{166}$

\section{Rights and Liabilities of Public Interest Intervenors}

The New Rules should adopt the restrictions as to costs used in Ivamy, making the public interest intervenor unable to seek costs against the parties and liable for any additional costs occasioned by the intervention. ${ }^{167}$ The rights and liabilities of public interest intervenors should be less than those of party intervenors. A public interest intervenor should not have the right to appeal the court's decision in a proceeding in which they have intervened. Such an approach will reduce any potential detrimental effects that the intervention could have on the parties. This is the position recommended by Kenny and Williams in Australia. ${ }^{168}$

\footnotetext{
164 Auckland Area Health Board, above n 44.

165 See Beyond the Door-Keeper, above n 111, para 6.31.

166 Williams makes the same recommendation. See Williams, above n 9, 400.

167 Ivamy, above n 29, 634 Cooke P for the Court.

168 Williams, above n 9, 401; Kenny, above n 100, 170.
} 
A concrete rule on this matter would clear up the current confusion caused by the suggestion from Hosking that a public interest intervenor could be liable for more than the additional costs occasioned by intervention. Such a suggestion is inappropriate and should not be adopted. ${ }^{169}$ It would burden the public interest intervenor with costs and is unnecessary to ensure justice to the parties.

\section{Applications for Leave to Appear as a Public Interest Intervenor}

The approach to processing applications for leave to intervene set out in Rule 57 of the Rules of the Supreme Court of Canada should be adopted and used. ${ }^{170}$ This Rule requires the applicant to state the interest they have in the proceeding, including any prejudice they might suffer if the intervention were denied. The application must also briefly outline the submissions the applicant intervenor intends to advance, "their relevance to the proceeding and the reasons for believing that the submissions will be useful to the Court and different from those of the other parties."171 Applications for leave to intervene should be decided on the papers, with hearings being held only in exceptional circumstances. ${ }^{172}$ This system would minimise the court time taken up in processing such applications.

There is currently no set format for application to appear as a public interest intervenor in New Zealand, though, as noted above, the Court in Drew suggests that an affidavit outlining the applicant intervenor's useful experience should be included. ${ }^{173}$ As a comprehensive codification of the formal requirements for such applications, a streamlined rule such as the Canadian example would reduce the time spent determining questions of leave to intervene. A dedicated rule setting out the form for public interest intervention applications would also reduce the confusion between different types of intervention that has been complained of in the United Kingdom.

\section{E Time for Filing}

As is the case for the Supreme Court of Canada, applications for leave to intervene should be required to be filed by a certain date after proceedings have commenced or an appeal has been lodged. ${ }^{174}$ At present there is no such time limit in New Zealand. This rule is needed to allow the

169 See Hosking, above n 25, para 16 Randerson J.

170 Williams recommends the adaptation of Rule 9(6) of the Rules of the Constitutional Court of South Africa, which sets out a procedure virtually identical to that in Rule 56 of the Rules of the Supreme Court of Canada. See Williams, above n 9, 400.

171 Rules of the Supreme Court of Canada 2002, r 57(2)(b).

172 See Williams, above n 9, 400.

173 See Part III B 2 Principles governing public interest intervention.

174 The relevant rule in Canada is Rule 56 of the Rules of the Supreme Court of Canada 2002. 
courts to deal with all applications for leave to intervene together. ${ }^{175}$ Such joint consideration gives the court the opportunity to consider each application for leave in the context of the litigation as a whole, avoiding piecemeal decisions on leave. ${ }^{176}$ There is no particular length of time which is appropriate, but the time limit chosen should be such as to allow the court to properly consider all applications for leave to intervene well before the date of the hearing.

\section{F Criteria to be Applied in Determining Whether Leave to Appear as a Public Interest Intervenor Will be Granted}

The New Rules should set out the criteria which the courts will apply in determining whether leave to appear as a public interest intervenor will be granted. The criteria adopted should be the "useful and different" and interest requirements used in Canada. ${ }^{177}$ These criteria require that an applicant intervener must have some interest in the proceedings, broadly speaking, and that their proposed submissions are useful and different from those of the parties. ${ }^{178}$ Such criteria are largely similar to those laid down in Drew, Ivamy and Woolworths, but codification of those existing principles would still be very useful in making this complicated area of law more transparent.

It may also be appropriate in some cases to make the grant of leave "conditional upon separate, but similar, interests combining to file a joint submission."179 This would reduce the time and cost burden on both the court and the parties. ${ }^{180}$

\section{G Restrictions on the Manner of Public Interest Intervention}

The approach outlined in the Rules of the Supreme Court of Canada 2002 should be adopted. ${ }^{181}$ The granting of leave to appear as public interest intervenor should only entail the right to present

175 Kenny, above n 100, 170.

176 Kenny, above n 100, 170.

177 See Part IV A 1 Rules from 1987-2002. Williams advocates the adoption of the Canadian criteria in Australia, stating "[t]hese criteria have worked effectively in Canada and would do so in Australia", Williams, above n 9, 400 .

178 Liberal application of the interest criterion is consistent with the core rationale behind public interest intervention - assisting the courts in reaching better decisions. It would be undesirable for the courts to refuse to hear useful submissions solely because the group wishing to intervene did not have a sufficiently direct legal interest in the proceedings. Conversely, groups who wish to intervene simply to contribute additional weight to the arguments of one of the parties should be filtered out through a strict application of the "useful and different" requirement.

179 Williams, above n 9, 401; see also Bryden, above n 2, 527.

180 Groups who would be expected to fulfil these criteria include human rights advocacy groups, minority advocacy groups, political pressure groups, trade unions, industry associations, the Attorney-General and other government bodies such as the Human Rights Commission. There is nothing in the criteria which would prevent a concerned individual from applying for leave to intervene, but an individual is less likely to be able to fulfil the useful and different criterion. 
written submissions. The question of whether or not to allow oral submissions should be considered separately. Although the orders made in Drew as to the manner of intervention are similar in effect to this proposed rule, ${ }^{182}$ it is not clear that these orders can always be made. Codification is therefore necessary to clarify the law.

The time allotted for oral submissions should be left to the discretion of the judge, but should generally be brief. The adoption of a Canadian-type system would allow the court access to the expertise of the public interest intervenor to the extent that it believes is necessary while also reducing the time and cost occasioned by the intervention.

\section{H Restrictions on the Scope of Intervention}

Intervenors should be required to stay within the original parameters of the case. They should not be allowed to expand the range of issues in dispute. ${ }^{183}$ Public interest intervenors are concerned with the points of law at issue in a particular case, not with the private dispute of the parties. ${ }^{184}$ The New Rules should thus give the judge granting leave to intervene the ability to restrict the issues on which the public interest intervenor is permitted to intervene. This will prevent inappropriate expansion of the issues feared by some commentators discussed above, and reduce any potential increase in costs that the intervention may occasion. No such rule of law currently exists in New Zealand, but it must be introduced if a system of public interest intervention is to work effectively.

\section{CONCLUSION}

The current law on intervention in New Zealand does not adequately accommodate public interest intervention. Judges are indisputably law-makers, and it is appropriate that they hear the perspectives of those non-parties who are affected by their decisions. Some form of public interest intervention ensures that such perspectives are heard.

New Zealand already has a form of public interest intervention, as do all the overseas jurisdictions this article has examined. Like New Zealand, Australia and the United Kingdom rely on the common law to regulate public interest intervention. Only Canada has a well-developed system of rules to regulate public interest intervention. Examination of overseas experience and the principles underlying public interest intervention shows that such rules are necessary to ensure that the advantages and disadvantages of public interest intervention are properly balanced. A clear

181 See Part IV A 2 Rules from 2002.

182 See Drew, above n 33, 432 McGrath J for the Court. The main difference between the approach taken in Drew and the Canadian approach is that the Canadian system determines the question of whether oral submissions will be allowed before the hearing, while the court in Drew left the decision until the hearing itself.

183 See Williams, above n 9, 401.

184 Bryden, above n 2, 526. 
system of rules also means that all the stakeholders in the system - lawyers, intervenors, judges, and parties - are fully informed of the way in which public interest intervention will be administered.

The New Rules set out above in Part VI draw on the current law of public interest intervention in New Zealand as well as overseas trends, and their adoption would develop and clarify the law of public interest intervention while balancing all the competing interests. These rules would:

(1) Clarify the role of the Attorney-General as a public interest intervenor;

(2) Create a single category of public interest intervenor, distinct from party intervention and appearance as amici curiae;

(3) Set out the rights and liabilities of public interest intervenors;

(4) Set out a clear process for the hearing of applications for leave to appear as a public interest intervenor;

(5) Set a time limit for the filing of applications for leave to intervene;

(6) Outline the criteria to be applied in determining whether leave to intervene will be granted;

(7) Give the court discretion to limit the manner of intervention; and

(8) Give the court discretion to limit the scope of the intervention.

These changes would be important steps towards escaping the outmoded approach of a strict inter partes system and acknowledging the wider law-making function of the judiciary. 
